\title{
Clustering K-Means Algorithms and Econometric Lethality Model by Covid-19, Peru 2020
}

\author{
Javier Pedro Flores Arocutipa ${ }^{1}$ \\ Universidad Nacional de San \\ Agustín, Arequipa, Perú
}

\author{
Jorge Jinchuña Huallpa ${ }^{2}$ \\ Universidad Nacional de Moquegua \\ Moquegua, Perú
}

\author{
Gamaniel Carbajal Navarro ${ }^{3}$ \\ Luís Delfín Bermejo Peralta ${ }^{4}$ \\ Universidad José Carlos Mariátegui \\ Moquegua, Perú
}

\begin{abstract}
Objective: The study looks at how the Covid-19 wave was in Peru, where and when it begins, where and when it culminates. As it faced, the shortcomings that were detected and especially that very little could be done to confront the disease as an emerging country. The wave began in May and ended in August with the greatest number of deaths and then fell. Methodology: Basic, explanatory level, with SINADEF data by region, of the situation room, to get the number of deaths, between January and September 2020/2019. Results. The relationship between infected and deceased was found a Pearson Rho of 0.94. The total death toll model depends on Lima, Huánuco, and Piura. The differences between the deaths of 2019 and 2020 were corroborated with the ANOVA, where a bilateral sig of 0.042 was got. The COVID cycle is found in the cluster algorithm model, of the nine months in $44.4 \%$ of them, it generated the highest lethality, between May and August. Conclusion. It is proven that COVID devastated regions of Peru. The model generated by the K-Means algorithm tells us that the COVID-19 cycle began in March and reached its highest peak of deceased and then descended.
\end{abstract}

Keywords-Infected; lethality; COVID 19 cycle; razing

\section{INTRODUCTION}

From March to October 2020, COVID-19 completed its cycle and showed the health crisis in Peru. The first wave would have passed, and it left 90 thousand dead according to SINADEF. Could anyone claim they existed, strategies with positive results against COVID-19? The answer is no. From Iquitos, Ucayali, Piura, Callao, Arequipa, Moquegua, Ica among other regions, allows us to compile what happened, since the MINSA, Essalud, and Diresas, [2] do not yet find the way, of what needs to be done in a holistic and holistic approach to prevention, diagnosis, treatment, and recovery.

The work of [3] also demonstrates the enormous number of deaths is in inverse relation to the shortage of doctors, beds, and Public expenditure per capita, in 30 countries of Europe. The car showed fewer inputs for the disease, more deceased. However, the investigation finds [4] that the greatest number of deaths are related to corruption rates, calling them risk factors.

There were little prevention and minimal targeted action. Although public policies propose that molecular testing is vital in diagnosis; it still uses rapid testing. They have caused more problems and are not blunt. The MINSA uses rapid antigen detection tests, erratic measurement since rapid tests are not useful for early diagnosis because such a test only finds antibodies from day 10. Therefore, thousands of patients did not receive timely treatment, increasing the number of deaths in and outside the hospital, which reached its peak in May and then followed other regions, until August.

What did doctors learn from the experience between May and August in Peru?

In May 2020, they said that in Iquitos, Ucayali Piura, Callao; cases were decreasing. However, specialist and nonspecialist people were focused on taking medicines to avoid reaching the third phase of the disease, a critical stage between life and death. Another is the lack of knowledge that COVID patients developed pneumonia, which led doctors in the regions to use very early tomography scans. The patient, on the third, fourth, and fifth day of illness, had a CT scan whose reports showed lung involvement (10\% to 30\%). The treatment showed apparently harmed the patient and sped up the path to the grave.

It can be concluded that from Iquitos to Tacna in Peru, they had the same problems because they used the same strategies even though they had 2, 3, or 4 months to prepare. And if they did, it did little good.

In Table I, the timeline of what happened between January and October in the world takes us that there is always a month or a "peak" day where there was the greatest number of deaths, it is infected who generate after days the number of deaths. For example, the highest number of deaths in China was on February 22, in Spain and Italy was the last third of March, the United Kingdom, and France reached the highest number of infected and deceased in April. Russia and Ecuador had in May, Peru had its hard month in June, Brazil in July, and Argentina with Colombia in August.

\section{Methodology}

It is a basic study of descriptive level, with the nonexperimental design of the explanatory level. The analysis was mortality by regions in 2020. SINADEF, the Ministry of Health, and the regional health directorates of the regions of Peru were contacted. We tabulated the data of 24 regions in infected and deceased, included in some steps by districts to observe the difference between urban and rural. Pearson's coefficient of determination and correlation and K-Means algorithm was applied. And variance analysis for related samples. Groups of regions have been defined by stages as they reached the maximum number of deaths in this PO. 


\section{RESUlTS}

The COVID 19 cycle in the world (Table I) shows peak dates. Thus, the maximum number of daily infected in the first wave (PO) in the United States, occurred on April 4 with 34582 daily, in the second wave was on July 2 with 79651 infected and in the third cusp that was on December 11 with 247414 infected. The highest number of daily deaths was on April 21 with 2743 deaths, on July 30 with 1853, and on December 9 with 3263. In France, in the first wave, it had a maximum of infected, on March 31 with 7578 infected and in the second wave on November 7 with 88790 daily. Those who died on April 15 were 1437, in the second wave (SO), on November 13, with 932 deaths. In Italy, on 21 March, the number of cases infected was 6554, while in the second wave, on 13 November, it was 40896. The deaths on March 27 of 921 died, in the second wave, December 3, with 993. In the UK in the PO the maximum arrived on April 10 with 7860 infected. In the OS on November 12 with 33470 infected. So also, in the PO, on April 21 with 1166 deaths while in the SO on November 25 with 696 deaths. In Spain, on March 20, in the PO the maximum daily was 10654 , and in the OS on October 27 with 22641 infected, the maximum number of deaths in the PO was on April 2 with 996 deaths and in the OS the maximum daily was on November 24 with 537 . This scenario leads us to ask how was the approach of COVID 19 in the world and especially in Peru by regions in the first wave (PO)?

In the PO, in January 2020, the OMS proclaimed to the world the disaster of the COVID-19 outbreak, which advanced at an indescribable speed, becoming the worst pandemic of this century. It started in China, crossed the countries of Europe, and reached Latin America in a few weeks. In Peru, according to medical specialists (infectologists, epidemiologists, among others) "raze" from Iquitos to Tacna, collapsing the supply of the health sector, exposing the deficiencies of infrastructure, its equipment, logistics of medicines, besides the competencies "in crisis" by health workers, expressed by fallacies in the treatment and use of medicines, who through ignorance and uncertainty used medicines - now withdrawn and outside the protocols of the MINSA - such as Azithromycin, Ivermectin, Hydroxychloroquine [1], including chlorine dioxide.

In the regions of Peru, what could be done? In Table II, we can observe it that the regions reached their highest peak of deaths during May, June, July, and August. In the first group are; Callao, Loreto, Ucayali, and Piura where the highest level of deceased, was in May (Fig. 1), then there is, Ancash, La Libertad, Lambayeque, Lima, Madre de Dios, San Martin, and Tumbes, here the highest ridge occurred in June (Fig. 2). In third place are the regions Amazonas, Arequipa, Cajamarca, Huánuco, Ica, Junín (Fig. 3) that had the highest number of deaths in July, and close with Ayacucho, Cusco, Huancavelica, Apurímac Moquegua Pasco, Puno, and Tacna in August (Fig. 4). Everything suggests that there was never a real strategy against Covid in Peru, or the impotence of not being able to do anything. Then COVID 19 will "walk" around the country. After sweeping the northern regions it enters the center and then to the south, for August raze Puno, Moquegua, and Tacna. The razing concept I use [5] when he tells us that in the middle of the nineteenth century the various global diseases demolished (cholera) Europe, is not that there is nothing left but that anger did what it wanted with human beings in the West without problems that prevent it from being transnational (p.1). Table II shows that in Loreto, by March it had 211 dead, in April 474, and in May it reached the maximum of 1166 and then descend to 472 in June and in September to reach 229 dead. This is seen in all regions. Nothing prevented it from reaching the peak of death and then descending.

TABLE I. WORLD COVID-19 TIMELINE

\begin{tabular}{|c|c|c|c|c|c|c|c|c|c|}
\hline Countries & Jan & Feb & March & April & May & $\begin{array}{l}\text { Jun - } \\
\text { July }\end{array}$ & August & Sep & Oct \\
\hline China & \begin{tabular}{|l|} 
Jan- \\
22 \\
\end{tabular} & \begin{tabular}{|l} 
Feb- \\
22 \\
\end{tabular} & Mar22 & & & & & & \\
\hline Infected & 259 & 14108 & 40 & & & & & & \\
\hline Deceased & 8 & 142 & 22 & & & & & & \\
\hline Spain & & 8-Mar & 20-Mar & 2-Abr & $\begin{array}{l}8- \\
\text { May }\end{array}$ & 4-Jun & & & \\
\hline Infected & & 2221 & 10856 & 4618 & 344 & 360 & & & \\
\hline Death & & 7 & 262 & 961 & 213 & 25 & & & \\
\hline Italy & $\begin{array}{l}25- \\
\text { Feb }\end{array}$ & $\begin{array}{l}21- \\
\text { Mar }\end{array}$ & 27-Mar & \begin{tabular}{|l|}
$30-$ \\
May
\end{tabular} & \begin{tabular}{|l}
$30-$ \\
Jun \\
\end{tabular} & & & & \\
\hline Infected & 94 & 6554 & 5907 & 417 & 142 & & & & \\
\hline Deceased & 4 & 796 & 921 & 112 & 23 & & & & \\
\hline UK & & $\begin{array}{l}14- \\
\text { Mar }\end{array}$ & $10-\mathrm{Abr}$ & $\begin{array}{l}21- \\
\text { Abr }\end{array}$ & & 14-Jul & & & \\
\hline Infected & & 310 & 7860 & 3896 & & 398 & & & \\
\hline Deceased & & 18 & 1149 & 1166 & & 46 & & & \\
\hline France & & 9-Mar & 31-Mar & $\begin{array}{l}15- \\
\text { Abr }\end{array}$ & $\begin{array}{l}9- \\
\text { May } \\
\end{array}$ & & & & \\
\hline Infected & & 203 & 7578 & 2633 & 433 & & & & \\
\hline Deceased & & 3 & 498 & 1437 & 80 & & & & \\
\hline Russia & & $\begin{array}{l}27- \\
\text { Mar }\end{array}$ & & $\begin{array}{l}15- \\
\text { Abr }\end{array}$ & \begin{tabular}{|l|}
$29-$ \\
May \\
\end{tabular} & 1-Jul & 15-Ago & 6-Sep & 22-Oct \\
\hline Infected & & 196 & & 3388 & 8572 & 6556 & 5061 & 5195 & 15971 \\
\hline Deceased & & 1 & & 28 & 232 & 216 & 119 & 61 & 317 \\
\hline Ecuador & & \begin{tabular}{|l|}
$18-$ \\
Mar \\
\end{tabular} & 24-Abr & \begin{tabular}{|l|}
$4-$ \\
May \\
\end{tabular} & \begin{tabular}{|l|}
$10-$ \\
May \\
\end{tabular} & 14-Jul & 15-Ago & \begin{tabular}{|l}
$15-$ \\
Sep \\
\end{tabular} & 21-Oct \\
\hline Infected & & 154 & 7059 & 2178 & 407 & 1033 & 1189 & 1972 & 1510 \\
\hline Deceased & & 2 & 25 & 301 & 640 & 105 & 55 & 41 & 47 \\
\hline Peru & & & 22-Mar & \begin{tabular}{|l|}
$19-$ \\
May
\end{tabular} & \begin{tabular}{|l|}
$31-$ \\
May
\end{tabular} & $\begin{array}{l}17- \\
\text { Jun } \\
\end{array}$ & 5-Jul & $\begin{array}{l}16- \\
\text { Ago } \\
\end{array}$ & 22-Oct \\
\hline Infected & & & 32 & 4550 & 8805 & 3752 & 3638 & 10143 & 2991 \\
\hline Deceased & & & 2 & 271 & 253 & 302 & 163 & 206 & 47 \\
\hline Brazil & & & 1-Apr & 4-Jun & $\begin{array}{l}19- \\
\text { Jun }\end{array}$ & & 29-Jul & & 22-Oct \\
\hline Infected & & & 1163 & 31890 & 55209 & & 70869 & & 31985 \\
\hline Deceased & & & 41 & 1492 & 1221 & & 1554 & & 503 \\
\hline Argentina & & \begin{tabular}{|l|}
$31-$ \\
Mar \\
\end{tabular} & & & & & 29-Jul & $\begin{array}{l}22- \\
\text { Ago }\end{array}$ & 22-Oct \\
\hline Infected & & 159 & & & & & 8670 & 13056 & 8570 \\
\hline Deceased & & 2 & & & & & 380 & 400 & 172 \\
\hline Colombia & & & & $1-\mathrm{Abr}$ & \begin{tabular}{|l|}
$14-$ \\
May
\end{tabular} & $\begin{array}{l}10- \\
\text { Jun }\end{array}$ & 30-Jul & $\begin{array}{l}19- \\
\text { Aug }\end{array}$ & 22-Oct \\
\hline Infected & & & & 159 & 680 & 6803 & 9965 & 13056 & 8570 \\
\hline Deceased & & & & 4 & 21 & 61 & 380 & 400 & 192 \\
\hline
\end{tabular}

Note: The cycle in the world was not uniform began in China, and reached its highest level and continued with the other countries until August, which reaches Colombia and Argentina. The virus passed through the world. Source: https://www.worldometers.info/coronavirus/ 
TABLE II. DEATHS TIMELINE BY REGION

\begin{tabular}{|l|l|l|l|l|l|l|l|l|l|}
\hline \multicolumn{7}{|l}{ Peru, deaths: Timeline by region-2020 } \\
\hline Region & Jan & Feb & Mar & Apr & May & Jun & Jul & Aug & Sep \\
\hline Loreto & 189 & 191 & 211 & 474 & 1166 & 472 & 292 & 301 & 229 \\
\hline Ucayali & 215 & 144 & 171 & 369 & 761 & 282 & 229 & 186 & 143 \\
\hline Piura & 395 & 341 & 331 & 657 & 2239 & 1581 & 1046 & 1064 & 854 \\
\hline Lambayeque & 42 & 52 & 46 & 280 & 790 & 486 & 376 & 333 & 290 \\
\hline Callao & 346 & 386 & 404 & 652 & 1722 & 1577 & 1209 & 1065 & 743 \\
\hline Ancash & 473 & 465 & 492 & 531 & 1002 & 1160 & 1131 & 955 & 616 \\
\hline La libertad & 719 & 574 & 597 & 569 & 972 & 2309 & 2183 & 1259 & 838 \\
\hline Lima & 3220 & 3300 & 3792 & 5866 & 11910 & 12390 & 11508 & 11260 & 6851 \\
\hline $\begin{array}{l}\text { Madre de } \\
\text { Dios }\end{array}$ & 88 & 51 & 59 & 43 & 69 & 194 & 193 & 121 & 77 \\
\hline San Martin & 258 & 209 & 205 & 173 & 247 & 764 & 685 & 437 & 288 \\
\hline Tumbes & 114 & 82 & 97 & 122 & 288 & 336 & 172 & 131 & 105 \\
\hline Amazonas & 82 & 77 & 62 & 61 & 76 & 112 & 194 & 115 & 85 \\
\hline Arequipa & 579 & 576 & 566 & 576 & 657 & 1208 & 2647 & 1889 & 828 \\
\hline Cajamarca & 306 & 250 & 245 & 227 & 282 & 373 & 832 & 666 & 465 \\
\hline Huánuco & 280 & 240 & 250 & 242 & 272 & 377 & 532 & 480 & 309 \\
\hline Ica & 368 & 388 & 344 & 402 & 822 & 1231 & 1292 & 985 & 602 \\
\hline Junín & 523 & 500 & 550 & 427 & 638 & 713 & 1390 & 1186 & 736 \\
\hline Ayacucho & 174 & 155 & 135 & 135 & 177 & 174 & 251 & 317 & 229 \\
\hline Cusco & 573 & 496 & 479 & 447 & 454 & 516 & 798 & 1415 & 687 \\
\hline Huancavelica & 165 & 153 & 157 & 193 & 191 & 194 & 267 & 356 & 210 \\
\hline Apurímac & 131 & 132 & 121 & 140 & 161 & 175 & 188 & 248 & 245 \\
\hline Moquegua & 75 & 57 & 60 & 42 & 55 & 90 & 319 & 446 & 112 \\
\hline Pasco & 99 & 78 & 81 & 63 & 103 & 86 & 148 & 170 & 106 \\
\hline Puno & 377 & 414 & 358 & 347 & 385 & 406 & 715 & 1568 & 658 \\
\hline Tacna & 108 & 93 & 95 & 74 & 101 & 106 & 240 & 477 & 202 \\
\hline & & & & Note: The highest elevation started in May through August \\
\hline
\end{tabular}
regions.Source:https://www.minsa.gob.pe/reunis/data/defunctions_registered.sp

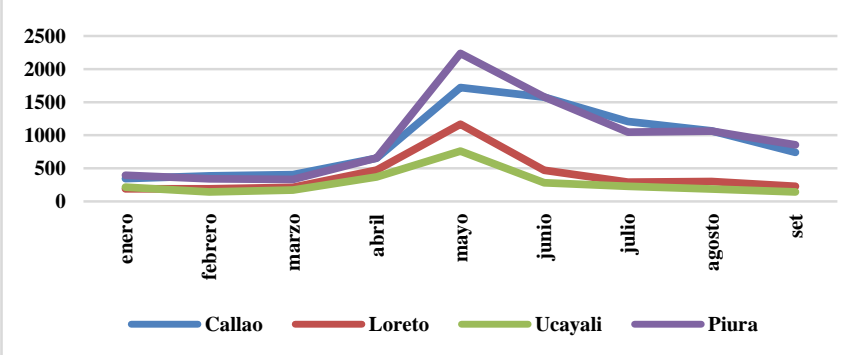

Note: The cycle reached its highest point in May, then fell.

Fig. 1. Regions with the Highest Deaths in May 2020.
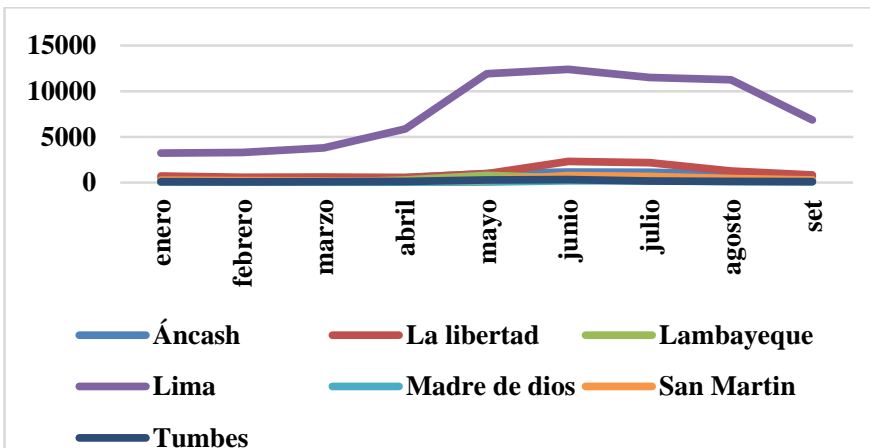

Note: The cycle reached its peak in June, then descended.

Fig. 2. Regions with the Highest Deaths in June 2020.

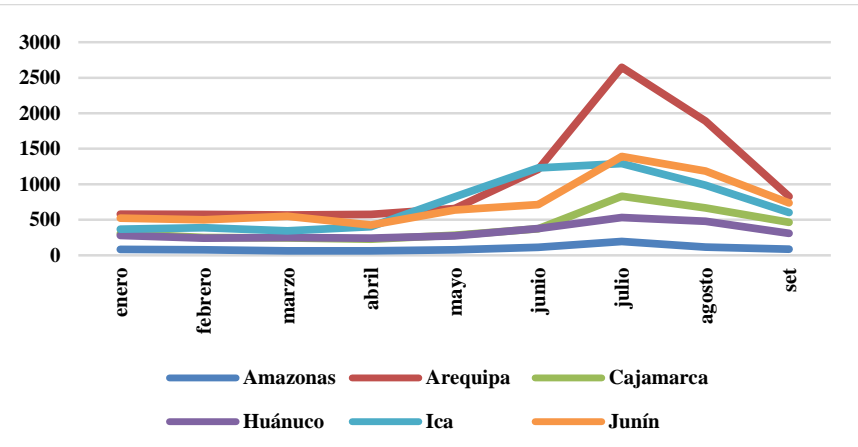

Note: The cycle reached its peak in July, then descended.

Fig. 3. Regions with the Highest Deaths in July 2020.

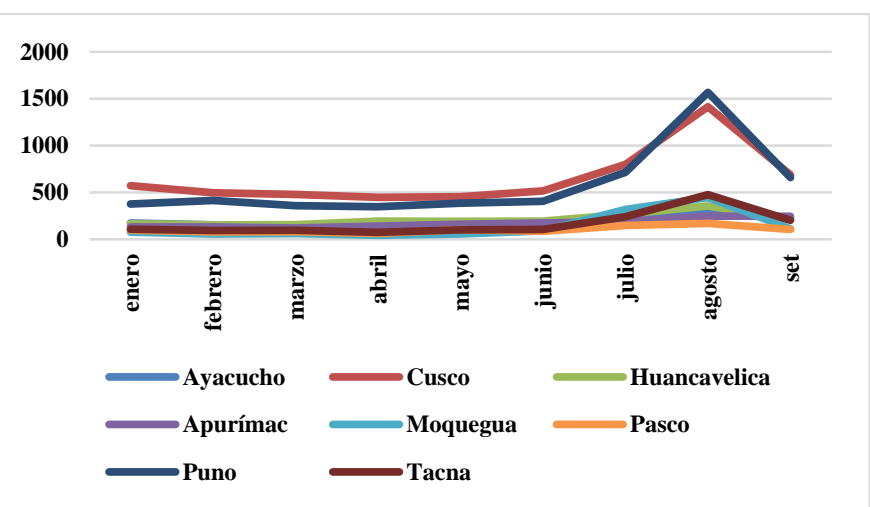

Note: The cycle reached its peak in August, then descended.

Fig. 4. Regions with the Highest Deaths in August 2020.

Between January and September of the years 2019 and 2020 (Table III), it made a comparison of the number of deaths for all concept. This according to SINADEF data and globally in the analysis period in 201969024 people died and in the year 2020, 167953, the difference, is an excess of 98926 deaths.

It is in Lima, where the greatest number of people died, from 22629 in the period January to September 2019 to 70097 in the period January to September 2020, a difference of 47418 people.

Then, the second region where more people died was Piura with 8508, there is an excess of 6431 people, in freedom the excess was 5262 people, in Arequipa with 4484 people in excess, also Ica with 3129 people in excess, Junín with 2826 people in excess, the silence that had 5292 people in excess, in Moquegua the excess was 667 people.

In 2020, 167950 people died between January and September. Of these, Lima concentrates $41.74 \%$, freedom $5.97 \%$, Arequipa $5.67 \%$, Piura 5\%, and Callao with $4.83 \%$. They are the first five regions in the death ranking.

The difference between the deaths in 2020 and 2019 was a total of 98926. And of these, Lima concentrates $47.9 \%$, La Libertad with $5.3 \%$, Arequipa with $4.5 \%$, Piura with $6.5 \%$, and Callao with $5.3 \%$. The percentage increase of the first five ranking regions leads us to point out that in the Lambayeque region the increase was $524 \%$, five times more. It went from 432 deaths to 2695 in 2020. 
TABLE III. DEAD TIME LINE ALL CONCEPT

\begin{tabular}{|l|l|l|l|}
\hline All concept deaths, by region 2019-2020 \\
\hline Region & Jan-Sep 2019 & Jan-Sep 2020 & Difference \\
\hline Callao & 2813 & 8104 & 5292 \\
\hline Loreto & 1205 & 3525 & 2320 \\
\hline Ucayali & 1190 & 2500 & 1310 \\
\hline Piura & 2077 & 8508 & 6431 \\
\hline Ancash & 3582 & 6825 & 3243 \\
\hline La Libertad & 4758 & 10020 & 5262 \\
\hline Lambayeque & 432 & 2695 & 2263 \\
\hline Lima & 22679 & 70097 & 47418 \\
\hline Madre de Dios & 498 & 895 & 397 \\
\hline San Martin & 1380 & 3266 & 1886 \\
\hline Tumbes & 705 & 1447 & 742 \\
\hline Amazonas & 548 & 864 & 316 \\
\hline Arequipa & 5042 & 9526 & 4484 \\
\hline Cajamarca & 1637 & 3646 & 2009 \\
\hline Huánuco & 1657 & 2982 & 1325 \\
\hline Ica & 3305 & 6434 & 3129 \\
\hline Junín & 3837 & 6663 & 2826 \\
\hline Ayacucho & 678 & 1747 & 1069 \\
\hline Cusco & 4383 & 5865 & 1482 \\
\hline Huancavelica & 1097 & 1886 & 789 \\
\hline Apurímac & 1101 & 1541 & 440 \\
\hline Moquegua & 590 & 1256 & 667 \\
\hline Pasco & 421 & 934 & 513 \\
\hline Puno & 2739 & 5228 & 2489 \\
\hline Tacna & 669 & 1496 & 827 \\
\hline TOTAL & 69024 & 167950 & 98926 \\
\hline & & & \\
\hline & & & \\
\hline
\end{tabular}

Note: The difference in deaths between January and September 2020 compared to 2019 was 98926.

In the same way Piura, with an increase of $310 \%$. Passed from 2077 to 8508 deceased. In Lima, the number of deaths increased by $209 \%$, from 22679 to 70097 . In Callao, the number of deaths increased from 2813 to 8104 , an increase of $188 \%$. In the ranking, Loreto is in fifth place with an increase of $192 \%$, from 1205 to 3525 deaths. The national average was $143 \%$.

The average percentage lethality rate between May 15 and August 1, 2020, in Peru was 3.09\%, meaning that for every 100 infected 3 had died.

The region with the highest rate was Ica with $6.81 \%$, meaning for every 100 infected people 7 had died. In Lambayeque in the same way (6.8\%). In Ancash, Piura, and Tumbes the deaths per 100 were 6 . In the same way in the Loreto and Libertad region where it was 5 per 100.

In Amazonas, Callao and Ucayali are three people out of 100 who died. In Ucayali, Arequipa, Lima, San Martin, Junín, Pasco, Apurímac, Puno, Huánuco, Tacna, and Cajamarca had 2 per 100. And in Madre de Dios, Ayacucho, Huancavelica, Moquegua and Cusco was one person dead for every 100 infected.
Today, it can be stated based on empirical evidence that 98.5 percent of the deceased are adults and older adults [6], in the same way, they observe it in the relationship between infection and lethality. This is quite high. Calculations have been made for 75 days between May and August 2020. In the regions, determination and correlation coefficients have been found that exceed 0.70 and reach 0.996 . The containment or self-containment measures have threatened mortality, as claimed [7], even though the infection did not stop. This should be investigated.

If the infected grow in proportion, the deceased will grow. This reality is definitively repeated in Ica, Ancash, La Libertad, Apurímac, San Martín, Moquegua, Pasco, Tacna, Huánuco, Callao that are above $0.97 \%$, another high impact group is, Ayacucho, Lima, Madre de Dios, Tumbes, Piura, Lambayeque, Ucayali, Arequipa (Table IV), which are above 0.94 or $94 \%$, in the third group are Loreto, Huancavelica, Cajamarca, Junín, Amazonas which are above $90 \%$ up to $94 \%$. Cusco has a ratio of 0.845 that is significant and high, but not as high as that of the Ica region

Concerning the levels of explanation of deaths by the variable infected, it can be said that this ranges from $81.6 \%$ to $99.1 \%$. All direct and meaningful.

There are differences (Table V) between those who died in 2019 and those who died in 2020. Sig. has been achieved, bilateral 0.042 denoting that the calculated $t$ is greater than the table t. Differences between the data are accepted.

TABLE IV. HIGHER INFECTED COVID-19 HIGHER LETHALITY

\begin{tabular}{|l|l|l|}
\hline Region & $\mathrm{R}^{2}$ & $\mathrm{R}$ \\
\hline Ica & 0.991 & 0.996 \\
\hline Ancash & 0.984 & 0.992 \\
\hline La Libertad & 0.983 & 0.991 \\
\hline Apurímac & 0.981 & 0.990 \\
\hline San Martín & 0.975 & 0.988 \\
\hline Moquegua & 0.971 & 0.985 \\
\hline Pasco & 0.963 & 0.981 \\
\hline Tacna & 0.958 & 0.979 \\
\hline Huánuco & 0.956 & 0.978 \\
\hline Puno & 0.949 & 0.974 \\
\hline Callao & 0.942 & 0.970 \\
\hline Ayacucho & 0.935 & 0.967 \\
\hline Lima & 0.934 & 0.966 \\
\hline Madre de Dios & 0.926 & 0.962 \\
\hline Tumbes & 0.926 & 0.962 \\
\hline Piura & 0.925 & 0.962 \\
\hline Lambayeque & 0.899 & 0.948 \\
\hline Ucayali & 0.897 & 0.947 \\
\hline Arequipa & 0.892 & 0.945 \\
\hline Amazonas & 0.866 & 0.930 \\
\hline Junín & 0.855 & 0.925 \\
\hline Cajamarca & 0.850 & 0.922 \\
\hline Huancavelica & 0.818 & 0.904 \\
\hline Loreto & 0.816 & 0.903 \\
\hline Cusco & 0.714 & 0.845 \\
\hline & & \\
\hline & & \\
\hline
\end{tabular}


TABLE V. MATCHED SAMPLE TEST

\begin{tabular}{|c|c|c|c|c|c|c|c|}
\hline \multicolumn{5}{|c|}{ Matched differences } & $\mathrm{t}$ & Gl & Sig. (bilateral) \\
\hline \multirow{2}{*}{ Avera ge } & \multirow{2}{*}{ Standard deviation } & \multirow{2}{*}{$\begin{array}{l}\text { Average of standard } \\
\text { error }\end{array}$} & \multicolumn{2}{|c|}{$95 \%$ difference confidence Interval } & & & \\
\hline & & & Inferior & Superior & & & \\
\hline$-3957,0$ & 9211,7 & 1842,35 & 7759,51 & 154,64 & 2,148 & 24 & ,042 \\
\hline
\end{tabular}

The results of sig. (bilateral) is less than 0.05 .

The econometric model that explains the total number of deaths by region is as follows:

TOTAL DEATHS $=-2081.89357334+$ $1.35125103834 *$ LIMA + 24.8222422247*HUANUCO + 2.10959941364*PIURA

$\mathrm{R}^{2}=0.9996,(0.0019)(0.0000)(0.0001)(0.0073) \mathrm{DW}(2.70)$

And it can be concluded that in the period January to September of the year 2020, the regions of Lima, Huánuco, and Piura that are the independent variables, explain in an R2 of 0.9996 the total of deceased given that, probabilistic is less than 0.05 and obviously, the Durwin Watson is 2.70 that being around 2 shows us it is an acceptable model.

We would like to know what the impact of the deaths in Lima is on the total number of deaths. In practice, it can be said that for each percent that the deaths in Lima increase, it has an impact of $0.40 \%$ on the total number of deaths in the country. Likewise, in Huánuco, for each percent of those who die has an impact of $0.46 \%$ on the national total.

If in Piura increases by one percent, the number of deaths the impact on the total deaths is $0.2 \%$. With certainty, we can say it that if the number of deaths in Lima increases by $10 \%$, the number of deaths in Peru will increase by $4.3 \%$. There's the regression model:

LOG $($ TOTAL DEATHS $)=1.83321127186+$ $0.436468121477 *$ LOG (LIMA) + 0.465169428114*LOG $($ HUANUCO $)+0.205749187226 *$ LOG (PIURA)

(0.0003) (0.0046) (0.0009) (0.0208) DW (2.42)

Another observation got when analyzing the regions; Arequipa, Puno, Tacna, and Moquegua, is when the greatest number of deaths are concentrated in the urban part and mainly in the capital city. In Arequipa in July, there were 2647 deaths of that total, 2147 died in Arequipa, while in Islay 81, Caylloma with 75, in Camana 50, in Caravelí 19, in Castilla 19, in Condesuyos two and Union 5.

The same happened in Puno. Two cities, San Roman, which is Juliaca, and Puno the capital. In August there were 1,568 people dead. And in San Román-Juliaca there were 580 and in Puno 431 dead. The summation generates 1000 people, then Huancané 111, Azángaro 72, Collao 63, Melgar 62, and so on. With Moquegua, it should be stated that the two provinces concentrate almost the total of the deceased. They are Marshal Nieto 311 and Ilo 121 deceased.
In Tacna, in August 477 people died, and in the four provinces, in Tacna 448 other provinces died, Jorge Basadre 14, Candarave 6, Tarata 9.

In conclusion, it can be said that the greatest number of deaths are in urban areas and linked to the capitals of regions, while in rural areas the penetration of the COVID was in a smaller proportion and from there also the low number of deaths.

COVID-19 has questioned us on multiple aspects related to decision-making in public health, from health communication to the legal bases of prevention measures, monitoring of infection-related behaviors [8], or the application of epidemiological models.

The algorithm found by regions has variability and are concentrated in some 9 months analyzed, which allows us to observe that three clusters have formed (Fig. 5), three groups are observed. And that is one of them: it concentrates the last results, pointing out that there is correlate in the chain and with quite marked lethality peaks. It was the months of May, June, July, and August (Table VI). It contrasts with what reality presents. The article Mathematical Physical Modeling [9] showed that peaks can be found two weeks in advance.

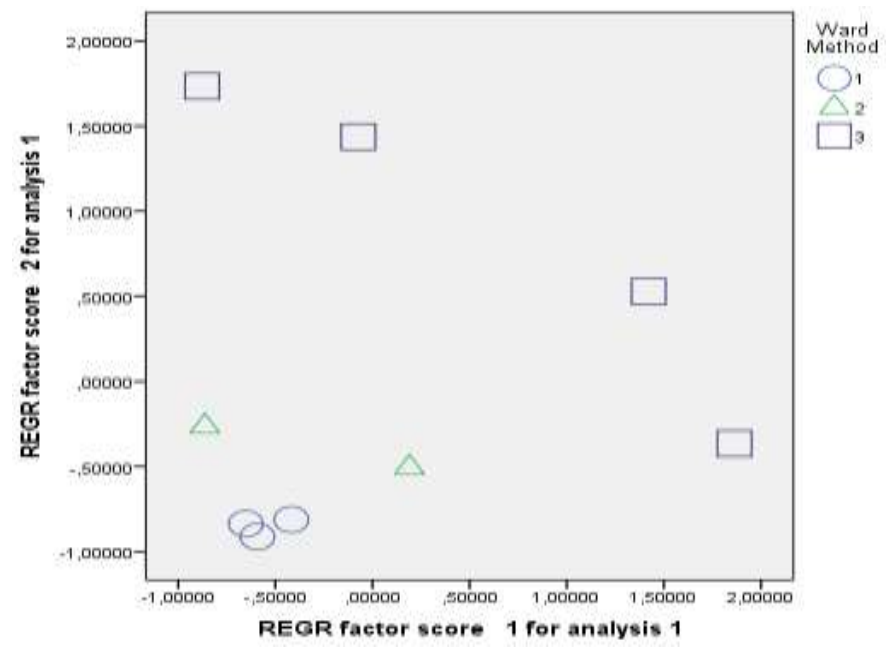

Fig. 5. Three Final Clusters. 
TABLE VI. FINAL CLUSTER CENTERS: LETHALITY BY REGION

\begin{tabular}{|c|c|c|c|}
\hline \multirow{2}{*}{ Regions } & \multicolumn{3}{|l|}{ Cluster } \\
\hline & 1 & 2 & 3 \\
\hline Callao & 378,67 & 697,50 & 1393,25 \\
\hline Loreto & 197,00 & 351,50 & 557,75 \\
\hline Ucayali & 176,67 & 256,00 & 364,50 \\
\hline Piura & 355,67 & 755,50 & 1482,50 \\
\hline Áncash & 476,67 & 573,50 & 1062,00 \\
\hline Libertad & 630,00 & 703,50 & 1680,75 \\
\hline Lambayeque & 46,67 & 285,00 & 496,25 \\
\hline Lima & 3437,33 & 6358,50 & 11767,00 \\
\hline Madre de Dios & 66,00 & 60,00 & 144,25 \\
\hline Martin & 224,00 & 230,50 & 533,25 \\
\hline Tumbes & 97,67 & 113,50 & 231,75 \\
\hline Amazonas & 73,67 & 73,00 & 124,25 \\
\hline Arequipa & 573,67 & 702,00 & 1600,25 \\
\hline Cajamarca & 267,00 & 346,00 & 538,25 \\
\hline Huánuco & 256,67 & 275,50 & 415,25 \\
\hline Ica & 366,67 & 502,00 & 1082,50 \\
\hline Junín & 524,33 & 581,50 & 981,75 \\
\hline Ayacucho & 154,67 & 182,00 & 229,75 \\
\hline Cusco & 516,00 & 567,00 & 795,75 \\
\hline Huancavelica & 158,33 & 201,50 & 252,00 \\
\hline Apurímac & 128,00 & 192,50 & 193,00 \\
\hline Moquegua & 64,00 & 77,00 & 227,50 \\
\hline Pasco & 86,00 & 84,50 & 126,75 \\
\hline Puno & 383,00 & 502,50 & 768,50 \\
\hline Tacna & 98,67 & 138,00 & 231,00 \\
\hline
\end{tabular}

\section{DISCUSSION}

In the papers analyzed, they show the cycle (Wave) of the COVID as can be seen in (Fig. 6) and its probable repetition, and perhaps in greater magnitude. It is known that the OMS pointed out in May that Brazil by August would have over 100 thousand dead, by the end of August this was 121 thousand dead [10]. It was said in the United States that the number of deaths would be 150,000 today reaches 400,000 . It should be pointed out that the Ministry of Health does not yet determine the actual number of deaths in Peru, according to SINADEF. As of 31 December, there are 37680 deaths. From the above, we already know that the figure reaches almost 100,000 deaths from COVID in December.

Adults and older adults are the passive of deaths, in Spain, they show it is an aged country where the over 65 years are a percentage of $19 \%$ that in total are 8.7 million people [11] but is a product of life expectancy (EV) as a component of the Human Development Index. People in Europe have an 84year-old EV just like France, Italy, and the UK.

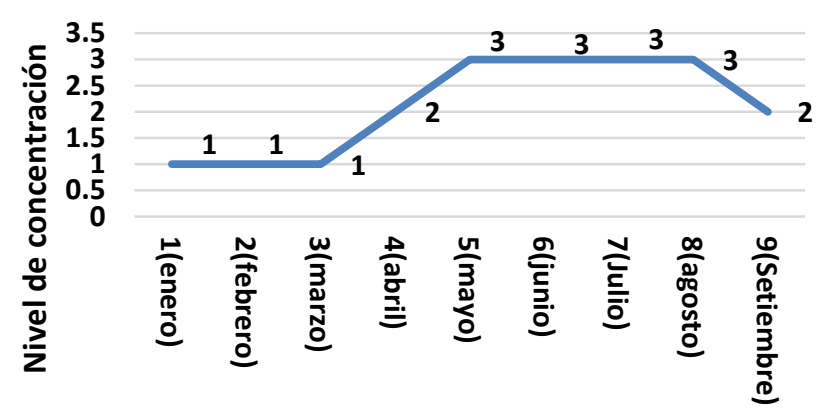

Source: Own elaboration

Fig. 6. Cluster De Pertinencia (3 Clusteres).The Three Segments denote the behavior of Lethality.

In [12] the same way, it has been showed in Peru that in $98.5 \%$, of the deceased are adults and older adults, other factors of death among the health sector's own servants are the EPP, which, while aimed at administrative procedures but not at the prosecution of infections.

In [1] fact, as in Latin America, COVID-19 devastates the critical health situation in emerging countries and, of course, in Peru. The infrastructure teams are not prepared to face the COVID even from the perspective of human capital and its remunerations, which are those they face in the first phase. Although in this work it is not presented in a concatenated way. We state that from February to August 2020 it affected in maximum figures. Asia and Europe, then when entering Peru begins in regions of the east, then the north, from there the center and arrive in the Peruvian South. And gradually from May to August, sweep with death and infected too much, demonstrating the weak infrastructure of MINSA and ESSALUD.

As he tells us [5] in the middle of the 19th century, the different cholera viruses devastated Europe, not that nothing is left but that cholera did what it wanted with human beings in the world, without problems that prevent it from being transnational. In Peru, this expression is accommodated, however, we would add to it that the Wave came from Iquitos and ended in Tacna.

From now on, Lima and Callao are concerned about the levels of infected and deceased because of the urban population, but outside it the ones that have the greatest incidence are Loreto and Piura [1], meaning that the COVID appropriates the urban sector.

The deceased [1] correspond to a segment of the population, so we note that $85 \%$ of those are over 70 years old. For this reason, many Peruvians have been asking for the restructuring of the health system, that it serves Peruvian citizens [1] and in this modern world, we already know that they are linked to the sectors most affected [13], which are tourism and trade.

In [14] Latin America, analyzing the number of deaths about the number of infected reported (lethality of the disease), it was found that Ecuador, Brazil, and Argentina recorded the highest frequency of deaths by COVID-19, with percentages of 
$8,3 \%, 6.5 \%$, and $4.4 \%$, respectively. Chile $1 \%$, Paraguay $(1.3 \%)$ and Venezuela (1.3\%) recorded the lowest frequencies in COVID-19 deaths.

The data suggest Chile is the South American country that presented the best coping strategy for COVID-19. [14], today is the best gains and implements the vaccine for its citizens.

Differences in [2], screening programs, as above, may underestimate the denominator and overestimate mortality rates if mild cases are not tested.

Age was associated with higher mortality, in our series, the highest proportion of deaths were in the age groups over 60 years, besides, that for every 10 years that the age increased, the risk of dying increased by $32 \%$, This was described in [15], a large series of Chinese population data, in which the age groups 60 to 69,70 to 79 and over 80 years had $3.6 \%, 8 \%$, and $14.8 \%$ mortality respectively.

In conclusion, the largest series of patients hospitalized with COVID-19 in the country was reported; the population tested presented high mortality and was associated with age, comorbidities, [16] inflammatory markers, and respiratory involvement. These results could serve us to propose strategies for reorganizing the care system and to direct management differentiating in [15] patients with higher risk factors for mortality.

All this has led OMS to come up with formulas for carrying out global mortality estimates; [17] and that they are ratified by the work of [18] that the mathematical model SIR generates for Colombia teaches us that the quarantine, hygiene, distancing and budget for the EPP do not cease to allow the greatest lethality.

Or as I try [19], that is why the author got that the referred lethality was $0.9524 \%$, is the average of $1.02 \%$, between 0.65 and $1.34 \%$ with 149 countries.

$80 \%$ of patients behave asymptomatic [20] as in Peru, and that in the absence of molecular evidence then becomes a factor of contagion and death.

The severity of COVID focuses on older adults in men rather than women and obviously, mechanical ventilation is a proportional aid. [21], [22], quarantine still influences the decrease in mortality.

If we point out that in Peru the case fatality rate was around $3 \%$ in China where the pandemic began, it was reported that the crude case fatality rate in [23] China was $2.3 \%$ in patients infected with SARS-CoV-2.

They are those over 40 years old, those who have a high risk of lethality [23], and that increases as the years go by. Dangerous is over 60 years of age.

\section{CONCLUSIONS}

COVID-19 demonstrated the precariousness of the health system in Peru, as in the countries of Asia and Europe, it toured the Peruvian east, then the north, it toured the center and devastated the Peruvian south and very little could be done to stop deaths. So, in May, he started in the east to end up in the south in the cycle of the highest number of deaths from
COVID-19 infection. The ratio between infected and deceased was on average quite high and direct 0.9 . The total number of deaths is explained by what happens in the regions of Lima, Huánuco, and Piura. There are differences between the deaths of 2020 and 2019.

In the developed countries, the United Kingdom, Italy, Germany, France achieves levels of explanation (R2) on an average of 0.98 and finally China with 0.8184 . Infection is a variable that influences and explains the behavior of deaths in the world.

The model generated by the K-Means algorithm shows the conglomerate is defined in the months of May-August, where the greatest lethality is concentrated. Above: March, April, or September.

The K-Means model shows us the behavior of lethality with fairly lofty peaks in the months mentioned.

\section{FUTURE WORK}

Future work will focus on comparative analysis of the behavior of the first and second waves of covid-19, proposed model with reviews software and 2020-2021 algorithms.

Effects of the covid-19 coronavirus on employment, family income and digital education in Peru, 2020 - 2021 using econometric models.

Algorithms that explain the effects of COVID 19 on tax collection, private and public investment in Peru 2021.

\section{REFERENCES}

[1] C. Maguiña Vargas, "Reflexiones sobre el COVID-19, el Colegio Médico del Perú y la Salud Pública Reflections on COVID-19 infection, Colegio Medico del Peru and the Public Health," Acta Medica Peru., vol. 37, no. 1, pp. 8-10, 2020.

[2] C. Maguiña, R. Gastelo, and A. Tequen, "El nuevo coronavirus y el desarrollo de la ciencia," Rev Med Hered, vol. 9, no. 2, pp. 5-6, 2020.

[3] E. Barrera-Algarin, J. L. Estepa-Maestre, Francisco Sarasola-SanchezSerrano, and A. Vallejo-Andrada, "COVID 19, neoliberalism and health systems in 30 countries in Europe: repercussions on the number of deaths. ," Rev. Esp. Salud Publica, vol. 94, p. 15, 2020.

[4] R. Mazzucchelli, A. Agudo Dieguez, E. M. Dieguez Costa, and N. Crespí Villarías, "Democracia y mortalidad por Covid-19 en Europa," Rev. Esp. Salud Publica, vol. 94, pp. 1-9, 2020.

[5] F. Lizaraso Caparó and J. C. Del Carmen Sara, "Coronavirus and global health threats," Horiz. Physician, vol. 20, no. 1, pp. 4-5, 2020, doi: 10.24265/horizmed.2020.v20n1.01.

[6] J. P. Flores Arocutipa, J. Jinchuña Huallpa, and R. T. Condori Perez, "Validation of an Econometric Model of Lethality for Infected People COVID-19, Peru Mayo 2020," Quipukamayoc, vol. 28, no. 57, pp. 1723, 2020, doi: 10.15381/quipu.v28i57.18396.

[7] Z. Yuan, Y. Xiao, Z. Dai, J. Huang, Z. Zhang, and Y. Chen, "Modelling the effects of wuhan's lockdown during covid-19, china," Bull. World Health Organ., vol. 98, no. 7, pp. 484-494, 2020, doi: 10.2471/BLT.20.254045.

[8] I. Hernández-Aguado and A. M. García, "Will public health be better after COVID-19? ," Gac. Sanit., No. xx, 2020, doi: 10.1016/j.gaceta.2020.06.004.

[9] H. E. Sánchez Vargas, L. Beltrán Ramos Sánchez, P. Á. Galindo Llanes, and A. S. Rodríguez, Salgado, "Modelación fisico-matemática para la toma de decisiones frente a la COVID-19 en Cuba Physicalmathematical modeling for decision-making against COVID- 19 in Cuba Luis Beltrán Ramos Sánchez Pablo Ángel Galindo Llanes Amyrsa Salgado Rodríguez Palabras clave," Retos Dir. 2020, vol. 14, No. 2, pp. $55-86,2020$ 
[10] N. Muñoz, "Covid-19 in Latin America: A first glance to the mortality," Colomb. Med., vol. 51, no. 2, pp. 1-2, 2020, doi: 10.25100/cm.v51ii2.4366.

[11] R. Fernández-ballesteros and S. Alonso, "Clínica y Salud," vol. 31, pp. 165-169, 2020.

[12] E. Galán-Rodas, A. Tarazona-Fernández, and M. Palacios-Celi, "Risk and death of doctors 100 days after the state of emergency by the COVID-19 in Peru," Acta Medica Peru., vol. 37, no. 2, pp. 119-121, 2020, doi: 10.35663/amp.2020.372.1033.

[13] N. Araújo Vila, "Economic impact of the pandemic caused by COVID19 at the global level. Analysis of the most affected sectors," Quipukamayoc, vol. 28, no. 57, pp. 85-93, 2020, doi: 10.15381/quipu.v28i57.17903.

[14] M. da C. N. Pinheiro, "Current situation of COVID-19 in South America," Point of view, p. 2, 2020, doi: 10.22354/in.v24i3.848.2.

[15] M. A. Vences et al., "Factors associated with mortality in hospitalized patients with COVID-19: Prospective cohort at the Edgardo Rebagliati Martins National Hospital," Scielo Prepr., no. 1, pp. 1-23, 2020, doi: 10.1590/SciELOPreprints.1241.

[16] E. P. Beriso, "COINFECTION SARS-COV-2 AND OTHER PATHOGENS," Rev. Esp. Salud Publica, pp. 1-4, 2020.

[17] WHO, "COVID-19 mortality estimation; scientific note. ," vol. 19, pp. $1-4,2020$.
[18] J. Homero, W. Visbal, and M. C. Castillo Pedraza, "Mathematical approximation of the SIR epidemiological model for the understanding of containment measures against covid-19," Rev. epañola Salud Pública, vol. 94, no. 22, pp. 1-11, 2020.

[19] Jesús I Simón Domínguez, Nadima Simón Domínguez, and Miguel A Reyes Núñez, "How to estimate the lethality of COVID-19," Rev. Mex. Patol. Clínica y Med. Lab., vol. 67, no. 1, pp. 4-8, 2020, doi: $10.35366 / 93845$.

[20] M. Á. Serra Valdes, "COVID-19. From pathogenesis to high mortality in the elderly and with comorbidities," Rev. Habanera Ciencias Médicas, vol. 19, no. 3, pp. 1-12, 2020.

[21] B. E. L. Manuel-Gamarra-villegas and K. E. Campos-correa, "Clinicalepidemiological characteristics and analysis of survival in deaths from COVID-19. attended in accommodation of the Red Sabogal-Callao 2020," Horiz Med, vol. 20, no. 2, p. e1229, 2020.

[22] P. F. Grillo-Rojas, R. Romero Onofre, and J. Aldana-Carrasco, "Comparison of early non-pharmacological interventions in COVID-19 mortality from Peru and the United States of America," Rev. la Fac. Med. Humana, vol. 20, no. 3, pp. 425-432, 2020, doi: 10.25176/rfmh.v20i3.3114.

[23] C. R. Aquino-Canchari, R. del C. Quispe-Arrieta, and K. M. Huaman Castillon, "COVID-19 and its relationship with vulnerable populations," Rev. Habanera Ciencias Médicas, vol. 19, pp. 1-18, 2020. 